Maria Korybut-Marciniak

Uniwersytet Warmińsko-Mazurski, Wydział Humanistyczny, Instytut Historii

ORCID 0000-0001-8196-5119

Karolina Studnicka-Mariańczyk

Uniwersytet Jana Długosza w Częstochowie, Instytut Historii

ORCID 0000-0002-4116-9350

\title{
Zielnik Marii Twardowskiej ( 1858-1907) jako pretekst do szkicu biograficznego kresowej botaniczki
}

\section{Maria Twardowska's (| 858-| 1907) Herbarium as a Pretext for a Biographical Sketch of the Borderland Botanist}

The article presents the figure of Maria Twardowska née Skirmunt (1858-1907), researcher of the Lithuanian flora, promoter of natural science, author of articles on botany, and social activist. Twardowska was one of the first women to conduct independent research on the Polish/Lithuanian flora. She published in 'Wszechświat' and 'Pamiętnik Fizjograficzny'. She kept scientific contacts with Polish botanists - Edward Janczewski, Józef Rostafiński, Władysław Dybowski, and Antoni Rehman. She is the author of the herbarium, which was in the collection of the Poznań Society of Friends of Sciences until the Second World War.

Keywords: herbaria, Borderlands in the $19^{\text {th }}$ century, women and botany, natural collections

Słowa kluczowe: zielniki, Kresy w XIX w, kobiety w botanice, kolekcje przyrodnicze

W 1908 r. na łamach „Roczników Towarzystwa Przyjaciół Nauk Poznańskiego” ukazała się krótka pośmiertna nota biograficzna Marii Twardowskiej ze Skimuntów ${ }^{1}$. Pobudką do zamieszczenia wspomnienia był zielnik przekazany Poznańskiemu Towarzystwu Przyjaciół Nauk mocą sporządzonego przez nią testamentu². Prezes Towarzystwa - Franci-

1 Nazwisko Skirmunt w źródłach i opracowaniach występuje w dwóch formach: Skirmunt i Skirmuntt. W tekście została przyjęta forma Skirmunt, zgodna z tą używaną przez Twardowską.

2 F. Chłapowski, Śp. Maria ze Skirmuntów Twardowska. „Roczniki Towarzystwa Przyjaciół Nauk Poznańskiego” t. 34,1908 , s. 317-320. 
szek Chłapowski (1846-1923) - wysoko ocenił wartość zapisu testamentowego. Jest on autorem pierwszego szkicu biograficznego Twardowskiej ${ }^{3}$. Zielnik nie zachował się w polskich zbiorach botanicznych. Zarówno jego losy, jak i postać autorki zasługują na przypomnienie.

Artykuł stanowi próbę przybliżenia życia i dokonań Marii Twardowskiej, badaczki flory litewskiej, popularyzatorki wiedzy przyrodniczej, autorki artykułów z zakresu botaniki. Należała ona do reprezentantek cichych emancypantek - Polek w guberniach północnozachodnich Cesarstwa Rosyjskiego, urodzonych w II połowie XIX w., które wykazywały się niezależnością w wyborze życiowych ścieżek, pracowitością, zaangażowaniem w zgłębianiu nauk i samodzielnością w pokonywaniu przeszkód w trudnych warunkach ucisku narodowego i kulturalnego ${ }^{4}$. Wymierzone wobec Polaków restrykcje, utrudniające dostęp do literatury i ograniczające działalność polskich organizacji naukowych i kulturalnych, w przypadku Twardowskiej nie stanowiły przeszkody w samokształceniu i nawiązywaniu kontaktów międzyzaborowych. Bohaterka artykułu jest jedną z pierwszych kobiet prowadzących samodzielne obserwacje polskiej/litewskiej flory. Jej nazwisko zostało utrwalone w botanice w nazwie rośliny - Hieracium Twardowskianum Rehman et Woł., gatunku jastrzębca występującego na Polesiu5.

\section{Życiorys i rodzina}

Źródła do biografii Marii Twardowskiej przedstawiają się skąpo. Nie dysponujemy aktami metrykalnymi, memuarami, zbiorem korespondencji, które mogłyby osadzić postać w środowisku rodzinnym i odtworzyć jej relacje. Rodzinne archiwum botaniczki, znajdujące się w Weleśnicy, spłonęło w czasie I wojny światowej. W zasobach archiwalnych i bibliotecznych zachowało się kilkanaście listów Twardowskiej o charakterze oficjalnym, będących przede wszystkim świadectwem jej kontaktów naukowych. Również źródła o charakterze prywatnym członków jej najbliższej rodziny przynoszą niewiele informacji. Podstawowym źródłem wiadomości na temat jej aktywności są artykuły, które publikowała w czasopismach naukowych i popularnonaukowych. Jej udział w badaniu flory ziem wschodnich dawnej Rzeczypospolitej został doceniony i zauważony w kilku publikacjach dotyczących botaniki w okresie II RP'. Pomimo tych luk źródłowych, operując dostępnymi informacjami, podejmujemy próbę szkicu biograficznego litewskiej florystki, botaniczki, kobiety nietuzinkowej.

Autorka ofiarowanego Poznańskiemu Towarzystwu Przyjaciół Nauk zielnika, Maria Twardowska ze Skirmuntów, była najstarszą córką Konstantego Skirmunta h. Dąb

3 Biogram Twardowskiej został zamieszczony w Słowniku biologów polskich; zob. J. Mowszowicz, Twardowska Maria (1858-1907), [w:] Słownik biologów polskich, red. S. Felisiak, Warszawa 1987, s. 548-549.

4 Zob. szerz. Niepodległość z kobiecą twarzą. Różne przejawy aktywności kobiet w drodze do niepodległości (od upadku powstania styczniowego do 1920 roku), red. T. Skoczek, Warszawa 2019; H. Ilgiewicz, Helena Romer Ochenkowska (1875-1947) i jej pamiętniki, [w:] Polskie dziwiętnastowieczne listy i pamiętniki z Ziem Zabranych - rola i miejsce w badaniach historycznych, red. W. Caban, L. Michalska-Bracha, Warszawa 2017, s. $475-488$.

5 Według obecnych ujęć taksonomicznych jest to odmiana jastrzębca kosmaczka i nazywa się Hieracium pilosella L. subsp. twardowskianum Rehmann \& Woł.

6 Zob. W. Sławiński, Przyczynek do znajomości okolic Wilna. Cz. 1 - Historia i bibliografia, Wilno 1922; B. Hryniewiecki, Udział kobiety polskiej w rozwoju botaniki, Warszawa 1993, s. 20-21. 
(1828-1880) i Gabrieli Umiastowskiej (1839-1922). Urodziła się w 1858 r. w - nie znamy dokładnej daty urodzenia, pojawiają się rozbieżności co do miejsca narodzin? Członkowie jej rodziny należeli do elity ziemiańskiej, byli pionierami przemysłu rolnospożywczego, inicjatorami modernizacji rolnictwa na Litwie oraz wybitnymi działaczami politycznymi. Jej dziad, Aleksander Skirmunt (1798-1870), absolwent Uniwersytetu Wileńskiego, zarządzał majątkiem przekraczającym 33 tys. hektarów, założył w swoich dobrach fabrykę sukna, gorzelnię, cukrownie i fabrykę świec i narzędzi rolniczych. Jest on uznawany za twórcę przemysłu fabrycznego w Pińszczyźnie ${ }^{8}$. Inni męscy członkowie rodziny również zaliczali się do awangardy życia gospodarczego Kresów PółnocnoWschodnich i brali aktywny udział w życiu politycznym. Na pierwszy plan wysuwa się Konstanty Skirmunt (1866-1949) -stryjeczny brat Twardowskiej, wiceprezes Grodzieńskiego Towarzystwa Rolniczego, członek Rady Państwa w Petersburgu, minister spraw zagranicznych w latach 1921-1922 w rządzie Wincentego Witosa9. Znane są również inne biografie członków jej najbliższej rodziny, którzy zaznaczyli swoją obecność na niwie społecznej, gospodarczej, politycznej i kulturalnej ${ }^{10}$. Rodzony brat Marii, młodszy od niej o trzy lata Kazimierz Skirmunt (1861-1931), absolwent Uniwersytetu Dorpackiego (studiował prawo) i Uniwersytetu Wrocławskiego (podjął studia rolnicze), postanowił zrzec się praw do majątku i obrał drogę kapłańską. Wyjechał do Rzymu, gdzie obronił doktorat z teologii i został radcą kanonicznym ambasady polskiej w Watykanie. Był orędownikiem otwarcia Papieskiego Polskiego Instytutu Kościelnego i pośrednikiem między episkopatem polskim a Stolicą Apostolską ${ }^{11}$. Bolesław Skirmunt (1869-1941) najmłodszy z rodzeństwa, dziedzic Szemetowszczyzny, propagator nowoczesnych metod uprawy, założyciel zakładów przemysłu rolnego w majątku został wybrany na członka I Dumy Państwowej Imperium Rosyjskiego z powiatu święciańskiego ${ }^{12}$. Maria pozostawała w cieniu członków rodziny, którzy w życiu publicznym odgrywali pierwszorzędną rolę.

Maria Skirmunt urodziła się w okresie międzypowstaniowym i należała do pokolenia Polaków, które doświadczyło intensyfikacji rusyfikacyjnej polityki caratu, zwłaszcza po upadku powstania styczniowego (eliminacja języka polskiego z życia publicznego, likwidacja polskiej kultury, prześladowania kleru katolickiego, redukcja polskiej własności ziemskiej) ${ }^{13}$. Dzieciństwo spędzała wraz ze swoim młodszym rodzeństwem - Kazimierzem, Józefą (1863-1899) i Bolesławem - w Szemetowszczyźnie koło Święcian (gubernia

7 Chłapowski podaje, że urodziła się w Mołodowie. Mowszowicz zamieścił w informację, że urodziła się w Szemetowszczyźnie; zob. F. Chłapowski, op. cit., s. 319; J. Mowszowicz, op. cit., s. 548.

8 S. Konarski, Aleksander Skirmunt 1798-1870, [w:] Polski Słownik Biograficzny, t. 38, Wrocław 1997-1998, s. $175-176$.

9 Zob. M. Nowak-Kiełbikowa, Konstanty Skirmunt (1861-1931), [w:] Polski Słownik Biograficzny, t. 38, Wrocław 1997-1998, s. 177-183; eadem, Konstanty Skirmunt. Polityk i dyplomata, Warszawa 1998; R. Jurkowski, Ziemiaństwo polskie Kresów Północno-Wschodnich 1864-1904, Warszawa 2001, s. 302-318; K. Skirmunt, Moje wspomnienia 1866-1945, oprac. E. Orlof, A. Pasternak, Rzeszów 1998.

10 Roman Skirmunt - brat stryjeczny Twardowskiej - premier Białoruskiej Republiki Ludowej: zob. Cz. Brzoza. K. Stepan, Skirmunt Roman (1868-1839), [w:] Polski Słownik Biograficzny, t. 38, Wrocław 1997-1998, s. 184 197; Konstancja Skirmunt - siostra stryjeczna Twardowskiej - publicystka, popularyzatorka historii, rzeczniczka polsko-litewskiego pojednania, zob. D. Szpoper, Gente Lithuana, natione Lithuana. Myśl polityczna i działalność Konstancji Skirmuntt (1851-1934), Gdańsk 2009.

11 H. Fokciński, Kazimierz Skirmunt (1861-1931), [w:] Polski Słownik Biograficzny, t. 38, Wrocław 1997-1998, s. 177.

12 Ziemianie polscy XX wieku. Słownik biograficzny, t. 3, cz. 1, red. J. Leskiewiczowa, Warszawa 1992, s. 143.

13 Zob. szerz. R. Jurkowski, op. cit., s. 62-178. 
wileńska), w modrzewiowym, ozdobionym dwoma portykami barokowo-klasycystycznym dworze Skirmuntów, otoczonym około 20-hektarowym parkiem krajobrazowym. Majątek Szemetowszczyzna wraz z dworem odziedziczył ojciec Marii, Konstanty, a następnie przekazał go najmłodszemu synowi Bolesławowi ${ }^{14}$. Konstanty Skirmunt (18281880), choć nie dorównał aktywnością społecznikowską swoim braciom, uchodził za dobrego gospodarza i światłego obywatela - dbał o wykształcenie swoich oficjalistów, którym fundował zagraniczne stypendia, otworzył spółkę kredytową dla włościan (Spółka Szemetowska), która po kilku latach funkcjonowania przynosiła duże zyski, wspierał „kulturę krajową”, gromadząc w swoim dworze kolekcję dzieł sztuki polskiej oraz bibliotekę $^{15}$. Pierwsze nauki Maria pobierała w Szemetowszczyźnie, mając do dyspozycji prywatnych nauczycieli i bogate zbiory biblioteczne. Opanowała język francuski i niemiecki, a jej rodzice dbali o wychowanie córki w duchu poszanowania kultury narodowej. Już od najwcześniejszych lat przejawiała szczególne zainteresowanie botaniką. Według relacji Chłapowskiego greki i łaciny uczył ją jej młodszy brat Kazimierz ${ }^{16}$. Znajomość łaciny otworzyła jej drogę do naukowych dzieł z zakresu botaniki. W wieku 18 lat, chcąc zgłębiać wiedzę przyrodniczą pod okiem profesjonalistów, wyjechała do Krakowa i w wstąpiła na Wyższe Kursy dla Kobiet kierowane przez Adriana Baranieckiego (1828-1891). Był to pierwszy na ziemiach polskich zakład dający możliwość wyższego kształcenia kobiet. Założony w 1868 r. przez Baranieckiego zyskał szybko dużą popularność, zwłaszcza wśród kobiet z Kresów Wschodnich. Oferował wykształcenie w ramach pięciu wydziałów: historyczno-literackiego, przyrodniczego, artystycznego, gospodarczego, handlowego (na wydział handlowy nie było chętnych) ${ }^{17}$. Maria uczęszczała na wydział przyrodniczy, który oferował wykłady z astronomii, fizyki, chemii, botaniki, zoologii, mineralogii i higieny ${ }^{18}$. Kadrę pedagogiczną Kursów stanowili wybitni uczeni, wśród nich profesorowie Uniwersytetu Jagiellońskiego, Szkoły Przemysłowej, Szkoły Sztuk Pięknych, Seminarium Nauczycielskiego - dyrekcja zabiegała o zatrudnienie najlepszych specjalistów ${ }^{19}$. Maria pobierała dodatkowe, prywatne lekcje u Edwarda Janczewskiego (1846-1918), który był wówczas profesorem na katedrze anatomii i fizjologii roślin na Uniwersytecie Jagiellońskim. Janczewski był związany z Kresami - urodził się w Blinstrubiszkach na Żmudzi, ukończył wileńskie gimnazjum, a następnie studiował w Petersburgu. Ożenek również wiązał go z Litwą - pojął pannę z Hanuszyszek, Jadwigę Szetkiewiczównę, młodszą siostrę Marii Sienkiewiczowej (pierwszej żony Henryka Sienkiewicza) ${ }^{20}$. Pracę na Uniwersytecie Jagiellońskim podjął w 1873 r., a w latach 1901-1902 był rektorem uczelni². Dzięki jego naukowej opiece i kierownictwu Skirmuntówna zyskała wiedzę i nowe umiejętności - to on rozwinął w niej pasję do badań flory kresowej. Po trzech latach nauki powróciła w 1879 r.

14 R. Aftanazy, Dzieje rezydencji na dawnych kresach Rzeczypospolitej, t. 4, Wrocław - Warszawa - Kraków 1993, S. 368.

15 T. Żychliński, Złota księga szlachty polskiej, r. 4 [Dodatki], Poznań 1882, s. 438-440.

16 F. Chłapowski, op. cit., s. 317.

17 J. Rostafiński, Historia Kursów Wyższych dla Kobiet im. A. Baranieckiego, Kraków 1900, s. 1-7.

18 J. Kras, Wyższe Kursy dla Kobiet im. A. Baranieckiego w Krakowie 1868-1924, Kraków 1972, s. $28-29$.

19 Ibid., s. 27-32 i 96-108.

20 B. Szargot, Sentymentalny profesor. Ślady lektury w listach przyrodnika, „Rocznik Komparatystyczny” 2018, nr 9, s. 253-266.

21 Z. Kosiek, Janczewski Edward, Glinka-, [w:] Słownik biologów polskich, s. 223-224; T. Majewski, Edward Franciszek Glinka Janczewski (1846-1918), [w:] Złota Księga Uniwersytetu Jagiellońskiego, red. A. Zemanek, cz. 1, Biografie Uczonych, Kraków 2000, s. 75-82. 
do rodzinnego majątku. W kolejnym roku, 8 lipca 1880 r. poślubiła Józefa Twardowskiego h. Ogończyk (syna Kazimierza i Michaliny z Wołłowiczów), ziemianina, mieszkańca Weleśnicy pod Pińskiem, wnuka Józefa Twardowskiego - przedostatniego rektora Cesarskiego Uniwersytetu Wileńskiego ${ }^{22}$. Był on jednym z większych właścicieli ziemskich w powiecie pińskim - posiadał około 90 włók ziemi² ${ }^{23}$ Ślub 22-letniej Skirmuntówny odbył się domu rodzinnym w Szemetowszczyźnie ${ }^{24}$. Nie zachowały się źródła informujące o związku i nie wiemy, czy znajomość Marii i Józefem Twardowskim była wieloletnia, czy stanowiła realizację wcześniejszych projektów rodzinnych oraz na ile mąż popierał (czy tolerował) jej naukowe zainteresowania. Rodziny Twardowskich i Skirmuntów łączyły dobre relacje o czym świadczą mariaże pomiędzy członkami rodzin, np. małżeństwo Henryka Skirmunta (1835-1916) z Mołodowa z Marią Twardowską (1845-1905), córką Kazimierza Twardowskiego i Michaliny Wołłowicz. Reprezentanci rodziny Twardowskich współpracowali ze Skirmuntami również na niwie społecznej: Twardowscy przekazali Skirmuntom działkę w Pińsku, na której Aleksander Skirmunt (ówczesny marszałek piński) ufundował pierwszą w mieście instytucję edukacyjną - gimnazjum szlacheckie (1858 r. $)^{25}$. Bliskie relacje rodzin i ich sąsiedztwo skłaniają do przypuszczenia, że związek Marii i Józefa należał do małżeństw zaaranżowanych.

Po ślubie Twardowska przeprowadziła się do dziedzicznego majątku męża - Weleśnicy nad rzeką Jasiołdą (dopływ Prypeci), oddalonego 5 km od Pińska. Aleksander Jelski podkreślał walory gospodarcze i krajobrazowe dóbr weleśnickich: „Ziemia szczerkowomułowa, łąki, rezydencja piękna, rybołówstwo, lasu dostatek"26. Majątek położony był na początku szlaku wodnego, tzw. Kanału Ogińskiego, który łączył Prypeć z Niemnem. Dobra Twardowskich sąsiadowały z majątkami Skirmuntów: Porzeczem i Mołodowem²7, więc można przypuszczać, że po ślubie botaniczka nie odczuła osamotnienia, pozostając w kręgu bliskiej rodziny ${ }^{28}$. Często też odwiedzała Szemetowszczyznę, o czym świadczą jej florystyczne zbiory.

Zbudowany na przełomie XVII i XVIII w. przez pierwszego z rodu właściciela dóbr poleskich, Piotra Twardowskiego, klasycystyczny dwór w Weleśnicy należał do jednych z najokazalszych w powiecie pińskim. Bryłę budynku porównywano do zaprojektowane-

22 Rodzina Twardowskich h. Ogończyk wywodziła się z Wielkopolski. Majątki Weleśnicę i Chożyn na Pińszczyźnie nabył w końcu XVII w. generał Piotr Twardowski, zapoczątkowując poleską linię Twardowskich. Jego syn Józef Twardowski (1786-1840), rektor Uniwersytetu Wileńskiego, odziedziczył Weleśnicę i po zakończeniu pracy na uczelni oddał się życiu ziemiańskiemu. Weleśnicę objął po ojcu jego syn - Kazimierz Twardowski (1813-1886)، ożeniony z Michaliną Wołłowicz. Z tego małżeństwa urodził się Józef - mąż Marii Skirmunt - oraz Maria, która wyszła za Henryka Skirmunta. Zob. K. Niesiecki, Herbarz Polski, t. 9, Lipsk 1839-1845, s. 156; T. Żychliński, op. cit., t. 1, Poznań 1879, s. 379-380; R. Aftanazy, op. cit., t. 2, s. 148.

23 Rodzina Skirmuntów posiadała w tym powiecie ponad 2800 włók, to jest ponad 47 tys. ha; zob. X.Y.Z., Kartka z dziejów Kościoła Katolickiego w Rosyi. Biskupstwo Mińskie, Kraków 1887, s. 173-174.

24 T. Żychliński, op. cit., r. 3, s. 238.

25 E. Złobin, „Niechaj Polska zna, jakich synów ma”. Rok 1863 na Pińszczyźnie, „Echa Polesia” 2013, nr 1, s. 22.

26 A. Jelski, Weleśnica, [w:] Słownik geograficzny Królestwa Polskiego i innych krajów słowiańskich, red. B. Chlebowski, F. Sulimierski, W. Walewski, t. 13, Warszawa 1893, s. 314.

27 M. Marczak, Przewodnik po Polesiu, Brześć 1935, s. 137.

28 Szymon Skirmunt (1747-1835), założyciel linii mołodowsko-porzeckiej, nabył majątki Mołodów i Porzecze od ks. Michała Kleofasa Ogińskiego. Dziedzicem dóbr był Aleksander Skirmunt (1798-1870), dziad Marii Twardowskiej. Po jego śmierci Mołodów otrzymał Henryk Skirmunt (1845-1905), stryj Twardowskiej. Kolejnym właścicielem Mołodowa był syn Henryka, Henryk (1868-1939), poeta i muzyk, który zginął w Mołodowie 20 września 1939 r.; zob. R. Aftanazy, op. cit., t. 2, s. 81-82. 
go przez Carla Spampaniego dworu w Radziwiłłmontach ${ }^{29}$. Założony z tyłu domu ogród i park krajobrazowy schodził aż do płynącej nieopodal rzeki Jasiołdy. Po drugiej stronie rzeki ciągnęły się łąki, tworzące wiosną i jesienią malownicze rozlewiska ${ }^{30}$. Maria Twardowska miała w pobliżu domu doskonałe tereny do swoich florystycznych poszukiwań - ziemie podmokłe, zasilane mułem rzecznym były terenem bogatej w rzadkie gatunki roślinności. Harmonijne życie małżeńskie przerwała choroba męża. W 1884 r. uległ paraliżowi i do końca swoich dni pozostał kaleką. Maria opiekowała się małżonkiem, wzięła na siebie obowiązki zarządzania majątkiem i wyręczała go w sprawach służbowych, nie rezygnując przy tym ze swoich botanicznych obserwacji ${ }^{31}$. Eksplorowanie okolic Weleśnicy i Szemetowszczyzny, studiowanie dzieł naukowych europejskich botaników, praca nad naukowym opracowaniem litewskiej flory stały się jej celem życia. Józef Twardowski nie ingerował w zainteresowania florystyczne żony, dlatego też czas wolny mogła poświęcić swoim studiom. Alicja Piekiełko-Zemanek i Piotr Köhler, analizując jej kontakty naukowe i korespondencję, podkreślają, że była to jedna z pierwszych kobiet prowadzących samodzielne badania florystyczne na ziemiach polskich ${ }^{32}$.

\section{Działalność naukowa}

O erudycji i zaangażowaniu Twardowskiej w badania florystyczne mogą świadczyć artykuły, które publikowała we „Wszechświecie” i „Pamiętniku Fizjograficznym”. „Wszechświat” był tygodnikiem popularno-naukowym, ukazującym się w Warszawie w latach 1882-1910, skierowanym do osób interesujących się przyrodoznawstwem i naukami ścisłymi. Niezbyt obszerne teksty Twardowskiej zamieszczane na łamach pisma dotyczyły różnych aspektów nauk przyrodniczych. Ich rozpiętość tematyczna była bardzo szeroka. Autorka zamieszczała abstrakty artykułów z zagranicznych czasopism naukowych, publikowała doniesienia na temat badań europejskich botaników, relacje z podróży naukowych, przedstawiała notatki z zakresu wykorzystania roślin w produkcji, a także artykuły plasujące się poza głównym nurtem jej zainteresowań - z obszaru antropologii, fizjologii człowieka, geologii, zoologii, zjawisk meteorologicznych. Przykładowo w latach 1899-1901 na łamach „Wszechświata” zamieszono 21 artykułów Twardowskiej, dotyczących m.in. wegetatywnego rozmnażania drzew $^{33}$, technologii produkcji kauczuku na świecie ${ }^{34}$, przenoszenia nasion roślin przez mrówki (myrmekochorii) ${ }^{35}$, uprawy drzew kawowych w Afryce ${ }^{36}$, zapylania roślin przez

29 Rezydencja w Radziwiłłmontach, zbudowana przez Janusza Radziwiłła w Nowogródczyźnie, zachowała się fragmentarycznie do dnia dzisiejszego: część portyku, fragmenty budynków gospodarczych. Podobieństwo założeń architektonicznych może wskazywać, że projektantem dworu w Weleśnicy był architekt Radziwiłłów - Carlo Spampani.

30 R. Aftanazy, op. cit., t. 2, s. 148-149.

31 W. Dybowski, Ś.P. Maria Twardowska. Wspomnienie pośmiertne, „Dziennik Wileński” 1907, nr 286, s. 1; E. Jankowski, Wspomnienia ogrodnika, oprac. A. Szwejcerowa, A. Brachfogel, Warszawa 1972, s. 397; F. Chłapowski, op. cit., s. 317.

32 A. Piekiełko-Zemanek, P. Köhler, Józefa Rostafińskiego odezwa do nie botaników o zbieranie ludowych nazw roślin i udział w niej Marii Twardowskiej, „Kwartalnik Historii Nauki i Techniki” t. 31, 1986, nr 2, s. 473.

33 M. Twardowska, Odmiany roślin rozmnażające się tylko przez gałęzie, „Wszechświat” t. 18, 1899, nr 2, s. 2527.

34 Eadem, Z czego robi się kauczuk, „Wszechświat” t. 18, 1899, nr 46, s. 730-732.

35 Eadem, Rozpowszechnianie roślin przez mrówki, „Wszechświat” t. 19, 1900, nr 8, s. 123-124.

36 Eadem, Drzewo kawowe i jego uprawa w Afryce, „Wszechświat” t. 19, 1900, nr 12, s. 184-186. 
ptaki (ornitogamii) ${ }^{37}$, bobrów w Prusach Zachodnich ${ }^{38}$. Teksty są świadectwem jej szerokich zainteresowań i znajomości literatury z zakresu nauk przyrodniczych. Mimo nasilonej rusyfikacji na ziemiach litewsko-białoruskich i utrudnionego dostępu do fachowej literatury Twardowska zdobywała ukazujące się na ziemiach polskich i na zachodzie Europy monografie oraz czasopisma i wykazywała dobrą orientację w opracowaniach z zakresu nauk przyrodniczych. Należy pamiętać, że zgodnie z profilem tygodnika „Wszechświat” artykuły, które wychodziły spod jej ręki, miały na celu popularyzację wiedzy - stąd miały formę streszczeń i omówień. Twardowska przedstawiała aktualny stan badań przedstawianych zagadnień, podawała nazwiska autorów naukowych opracowań, odwoływała się do najnowszych ustaleń i teorii, prezentowała rezultaty projektów badawczych. Wiedzę czerpała z czasopism naukowych niemieckich i francuskich, m.in.: „Zeitschrift für Entomologie”, „Jahrbuch Der Naturwissenschaften”, „Prometheus: Illustrirte Wochenschrift über die Fortschritte in Gewerbe, Industrie und Wissenschaft", "Comptes rendus de l'Académie des sciences”, „La Revue des Deux Mondes"39. Na łamach „Wszechświata” ogłaszała również swoje własne obserwacje botaniczne z terenów Litwy ${ }^{40}$. Publikowała także artykuły dotyczące fauny tych terenów, np. opisywała zachowania bobrów w Weleśnicy ${ }^{41}$. Niektóre z zamieszczanych tekstów mają charakter sprawozdawczy ${ }^{42}$. Współpracę z redakcją pisma rozpoczęła w 1884 r. Regularnie publikowała w nim od 1889 r. W latach 1889-1906 na łamach „Wszechświata” ukazało się 86 tekstów sygnowanych jej nazwiskiem lub inicjała$\mathrm{mi}^{43}$. W numerze 50 czasopisma z grudnia 1907 r. pojawił się jej krótki nekrolog: „Zakończyła życie ś. p. Maria ze Skirmuntów Twardowska, gorliwa zwolenniczka nauk przyrodniczych, niestrudzona florystka, współpracownica przez długi czas «Wszechświata». Cześć i spokój jej pamięci"44.

„Pamiętnik Fizjograficzny”, rocznik wychodzący od 1881 r. w Warszawie, finansowany przez Kasę Mianowskiego był czasopismem, w którym publikowano wyłącznie materiały naukowe z zakresu botaniki, zoologii, geologii, meteorologii oraz antropologii. Twardowska była jedną z najpłodniejszych autorek artykułów z zakresu botaniki - łącznie na szpaltach pisma opublikowała 11 tekstów ${ }^{45}$. Pierwsze rezultaty badań flory litewskiej zostały ogłoszone w 1883 r. pt. Spis roślin znalezionych w okolicy Szemetowszczyzny na Litwie $^{46}$. Były to wyniki obserwacji, które prowadziła od 1878 r., czyli jeszcze w okresie

37 Eadem, Przykład przystosowania rośliny do zapylenia przez ptaki, „Wszechświat” t. 19, 1900, nr 16, s. $250-251$.

38 Eadem, Bobry w Prusach Zachodnich, "Wszechświat” t. 20, 1901, nr 26, s. 410-413.

39 Twardowska podawała nazwy czasopism, czasem nazwiska badaczy i konkretne artykuły, których streszczeń dokonywała. Przykładowo w numerach 28-30 „Wszechświata” z 1889 r. streściła artykuł Henriego Valigny; zob. M. Twardowska, Ciepło i życie, „Wszechświat” t. 8, 1889, nr 28, s. 440-443, nr 29, s. 462-464, nr 30, s. 477-479; por.: H. Valigny, La Temperature et la vie, „Revue des Deux Mondes” t. 93, 1889, nr 1, s. 176-201.

40 M. Twardowska, Notatka o kilku rzadszych roślinach flory litewskiej, „Wszechświat”, t. 10, 1891, nr 51, s. 814815; eadem, Notatka o skrzypach znalezionych na Litwie w r. 1901, „Wszechświat” t. 12, 1903, nr 8, s. 122 123.

41 M. Twardowska; Korespondencja wszechświata. Z nad brzegów Jasiołdy, „Wszechświat” t. 8, 1889, nr 30, s. 480-481; eadem, Roboty jesienne bobrów, „Wszechświat” t. 17, 1898, nr 30, s. 779-780.

42 Por.: Eadem, Jubileusz F. Cohna we Wrocławiu, „Wszechświat” t. 17, 1898, nr 18, s. 287.

43 We „Wszechświecie” spotykamy różne wersje podpisów pełnym nazwiskiem i imieniem: „Twardowska Marya”, „Marya ze Skirmuntów Twardowska”' oraz inicjałami: „M.T.”

44 „Wszechświat” t. 26, 1907, nr 50, s. 800.

45 Por. T. Majewski, Botanika w warszawskich czasopismach „Pamiętnik Fizjograficzny” $i$ „Wszechświat”, „Analecta" t. 14, 2005, nr 1-2, s. 151.

46 M. Twardowska, Spis roślin znalezionych w okolicy Szemetowszczyzny na Litwie, „Pamiętnik Fizjograficzny” t. 3, 1883, dział III, s. 274-291. 
panieńskim, w okolicach rodowego majątku Skirmuntów. W kolejnym roczniku „Pamiętnika Fizjograficznego" opublikowała artykuł Przyczynek do flory Pińszczyzny, w sprawie którego konsultowała się z Józefem Rostafińskim, o czym informowała we wstępie ${ }^{47}$. Tematem publikacji była flora z terenu dworu i wsi Weleśnica znaleziona w $1883 \mathrm{r}$. W tekście autorka podała spis 90 gatunków roślin występujących na badanym terenie ${ }^{48}$. W 1885 r. opublikowała komunikat dotyczący śluzowców na Litwie ${ }^{49}$. Ponadto w czasopiśmie znajdują się uzupełnienia spisów. Wyniki kontynuowanych w następnych latach badań florystycznych na terenie Weleśnicy i Szemetowszczyzny były ogłaszane w formie dodatków ${ }^{50}$.

W późniejszych numerach periodyku pojawiają jej kolejne opracowania z lat 18901902 pt. Spis roślin zebranych z Szemetowszczyzny $i$ Weleśnicy ${ }^{51}$ wraz z uzupełnienia$\mathrm{mi}^{52}$. Twardowska zbierała materiał roślinny w swoich rodzinnych okolicach - opisywała i oznaczała rośliny, które zebrała na różnych siedliskach, np. w zaroślach, lasach, polach, ogrodach, czy stanowiskach, np. na cmentarzach, na dziedzińcu folwarcznym. Dokładnie charakteryzowała każdy gatunek, odnotowywała miesiąc, w którym okaz został zebrany, częstotliwość występowania i odmiany występujące na objętym poszukiwaniami obsza$\mathrm{rze}^{53}$. W roku jej śmierci został opublikowany krótki artykuł suplementujący wcześniejsze wyniki badań pt. Notaty florystyczne z Szemetowszczyzny i Weleśnicy54. Trzy lata po jej śmierci redakcja czasopisma zdecydowała się opublikować jeszcze jeden jej tekst prawdopodobnie został przesłany przez Twardowską jeszcze za życia. Tym razem nie dotyczył on roślin z okolic dworów, w których przebywała, lecz był analizą zielnika profesora Uniwersytetu Wileńskiego Jana Fryderyka Wolfganga (1775-1859). Jego zielnikiem kresowa botaniczka zainteresowała się jeszcze w latach osiemdziesiątych XIX w. Nieco światła na genezę tego tekstu rzucają zachowane w Bibliotece Litewskiej Akademii Nauk im. Wróblewskich listy, które pisała do Józefa Bielińskiego ${ }^{55}$. Zachowało się 15 listów do lekarza-historyka z lat 1886-1895. Twardowska korzystała z jego pomocy - Bieliński

47 Eadem, Przyczynek do flory Pińszczyzny, „Pamiętnik Fizjograficzny” t. 4, 1884, dział III, s. 423.

48 Ibid., s. 423-433.

49 Eadem, Wiadomości o śluzowcach znalezionych w latach 1778-1883, „Pamiętnik Fizjograficzny” t. 5, 1885, dział III, s. 160-163. Mowszowicz błędnie podaje informację, że powyższy artykuł został zamieszczony na łamach „Wszechświata”; por. J. Mowszowicz, op. cit., s. 549.

50 Eadem, Dodatek do spisu roślin znalezionych w okolicach Szemetowszczyzny na Litwie [...] i dodatek do przyczynka do flory Pińszczyzny [...], „Pamiętnik Fizjograficzny” t. 8, 1888, dział III, s. 215-220.

51 Eadem, Spis roślin z Szemetowszczyzny i Weleśnicy w latach 1893-1894, „Pamiętnik Fizjograficzny” t. 14, 1896, dział III, s. 115-118; eadem, Spis roślin z Szemetowszczyzny i Weleśnicy, „Pamiętnik Fizjograficzny” t. 17, 1902, dział III, s. 95-99.

52 Eadem, Ciąg dalszy spisu roślin z okolic Szemetowszczyzny i z Weleśnicy, „Pamiętnik Fizjograficzny” t. 10, 1890, dział III, s. 261-272; eadem, Ciąg dalszy spisu roślin z okolic Szemetowszczyzny i z Weleśnicy, „Pamiętnik Fizjograficzny" t. 12, 1892, dział III, s. 199-208.

53 Ibid.

54 Eadem, Notaty florystyczne z Szemetowszczyzny i Weleśnicy, „Pamiętnik Fizjograficzny” t. 19, 1907, dział III, s. $41-43$.

55 Józef Bieliński (1848-1926) - lekarz, historyk medycyny i autor obszernych, źródłowych monografii dotyczących Uniwersytetu Wileńskiego i Uniwersytetu Warszawskiego. Jako praktykujący lekarz pracował w Kałuszynie, Wiatce, Chołunicy. Po przeprowadzce do Wilna w 1880 r., gdzie objął posadę lekarza wojskowego, rozpoczął zbieranie materiałów źródłowych do historii medycyny w Wilnie. Z czasem rozszerzył swoje zainteresowania i podjął się zamiaru opracowania dziejów Uniwersytetu Wileńskiego. Pracę musiał kontynuować w Turkmenistanie, gdzie został skierowany jako lekarz. Po osiągnięciu emerytury w 1901 r. zamieszkał w Warszawie, gdzie pracował nad historią Uniwersytetu Warszawskiego. Pełnił funkcję dyrektora Archiwum Oświecenia Publicznego. Zmarł w Warszawie, ale został pochowany w Wilnie na cmentarzu Bernardyńskim; A. Wrzosek, Bieliński Józef, [w:] Polski Słownik Biograficzny, t. 2, Kraków 1936, s. 52. 
miał dostęp do materiałów Wileńskiego Towarzystwa Lekarskiego, ponieważ wówczas kończył monografię dotyczącą jego historii (obejmującej lata 1805-1864) i miał do dyspozycji archiwum instytucji. Zielnik Wolfganga był własnością Wileńskiego Towarzystwa Lekarskiego. W oszczędnych i konkretnych pismach do Bielińskiego obok próśb o pomoc Twardowska oferowała usługę zwrotną: materiał biograficzny i ikonograficzny dotyczący rektora Uniwersytetu Wileńskiego Józefa Twardowskiego, dziada jej męża ${ }^{56}$. Bieliński zbierał wówczas materiały do trzytomowego dzieła Uniwersytet Wileński (1597-1831) i gromadził materiały do biografii jej pracowników. Twardowska prosiła o sprawdzenie konkretnych gatunków roślin w zachowanym zielniku Wolfganga, a następnie zdecydowała się na zrewidowanie części zielnika. Z uwagi na jej nieczęste i krótkie wizyty w Wilnie powodowane sytuacją rodzinną, poprosiła Bielińskiego o zatrudnienie osoby, która dokona przepisania notat Wolfganga i jego studentów opisujących florę Wileńszczyzny. Instruowała Bielińskiego, które opisy stanowią dla niej największą wartość; chodziło o konkretne gatunki, m.in. zawilce, a także o kompletność notatek - polecała, by pominąć te rośliny, o których miejscu występowania nie było żadnej adnotacji57. Jak wynika ze wstępu do artykułu w „Pamiętniku Fizjograficznym” dzięki pomocy Bielińskiego miała do dyspozycji około 1/3 zielnika Wolfganga. W tekście autorka zwróciła uwagę na rośliny występujące w okolicach Pińska pomiędzy 1822 a 1826 r. Zostały one zebrane przez ucznia Wolfganga, Stanisława Batysa Gorskiego ${ }^{58}$, następnie zweryfikowane i opisane przez profesora farmacji. Botaniczka prawdopodobnie podjęła się pracy komparatystycznej i miała zamiar dokonać porównania flory Pińszczyzny z lat dwudziestych XIX w. z występującą na początku XX w. Tego już na łamach czasopism naukowych nie zdążyła ogłosić. Wypisy z zielnika Wolfganga opublikowane przez Twardowską są dziś jedynym śladem po dziele profesora Uniwersytetu Wileńskiego; jak podaje Köhler, nie znane są dzieje jego florystycznej kolekcjis9.

Obok „Pamiętnika Fizjograficznego" i tygodnika „Wszechświat” Twardowska współpracowała z Iwowskim wydawnictwem zielnikowym „Flora Polonica Exsiccata”, dystrybuowanym przez botaników Antoniego Rehmana (1840-1917) i Eustachego Wołoszczaka (1835-1918). Do powyższego wydawnictwa dostarczała, w odpowiedniej liczbie, okazy roślin przez siebie zebrane i oznaczone. Przy okazji znalazła okaz nieznanego dotąd gatunku jastrzębca, który na jej cześć został opisany przez Rehmana i Wołoszczaka

56 Lietuvos mokslụ akademijos Vrublevskiụ biblioteka [LMAVB], f. 7-518, List Marii Twardowskiej ze Skirmuntów do Józefa Bielińskiego, Weleśnica 6 V 1886 r., k. 1; LMAVB, List Marii Twardowskiej ze Skirmuntów do Józefa Bielińskiego, Weleśnica 14 I 1887 r., k. 2 r-v.

57 LMAVB, List Marii Twardowskiej ze Skirmuntów do Józefa Bielińskiego, Weleśnica 2 II 1887 r., k. 5r-6v; LMAVB, List Marii Twardowskiej ze Skirmuntów do Józefa Bielińskiego, 4 IV 1887 r., k. 7; LMAVB, List Marii Twardowskiej ze Skirmuntów do Józefa Bielińskiego, Weleśnica 2 II 1888 r., k. 11-12; LMAVB, List Marii Twardowskiej ze Skirmuntów do Józefa Bielińskiego, Weleśnica 29 IV 1888, k. 13.

58 Stanisław Batys Gorski (1802-1864) - botanik, entomolog, lekarz, farmaceuta, uczeń Bonifacego Stanisława Jundziłła i Jana Wolfganga, zarządca ogrodu botanicznego w Wilnie i adiunkt na Akademii Medyko-Chirurgicznej. Przez lata gromadził okazy flory litewskiej, opisywał je przesyłał do naukowych konsultacji botanikom z europejskich ośrodków naukowych. Był autorem licznych zielników oraz prac naukowych, publikowanych i pozostających w rękopisie; zob. szerz. W. Sławiński, op. cit., Wilno 1922, s. 11-13; D. Wołkowycki, Zróżnicowanie szaty roślinnej pogranicza Europy Środkowo-Wschodniej i Północno-Wschodniej, [w:] Z Mazowsza na Polesie, Zróżnicowanie i ochrona szaty roślinnej pogranicza Europy Środkowej i Północno-Wschodniej, red. A. Obidziński, Warszawa 2010, s. 28.

59 P. Köhler, Zielniki botaników ośrodka wileńskiego z lat 1780-1840 w Kijowie, Krakowie i Wilnie, „Kwartalnik Historii Nauki i Techniki" t. 39, 1994, nr 1, s. 113. 
pod nazwą Hieracium Twardowskianum ${ }^{60}$. Władysław Dybowski, badacz jastrzębców na Nowogródczyźnie ${ }^{61}$, uznał Hieracium Twardowskianum z bardzo interesujący ${ }^{62}$.

Warte podkreślenia są naukowe kontakty, jakie nawiązywała botaniczka z Weleśnicy. Obok Bielińskiego korespondowała z przyrodnikami ośrodków naukowych na ziemiach polskich. Niestety mamy do dyspozycji tylko wyrywkowe ślady współpracy naukowej. Zachowało się siedem listów (z lat 1883-1888) Twardowskiej skierowanych do Rostafińskiego. Korespondencję z Rostafińskim zapoczątkowała ankieta, jaką krakowski botanik wystosował do mieszkańców ziem polskich w gazetach ukazujących się na terenie trzech zaborów. Ankieta dotyczyła nazewnictwa ludowego roślin, rodzajów upraw na danym obszarze, gatunków uprawianych i dzikich, wykorzystywanych w gospodarstwie domowym itd. Twardowska systematycznie dostarczała informacji na temat nazw, rodzajów oraz sposobów użytkowania roślin w okolicach Weleśnicy. Jej odpowiedzi na pytania ankietowe były szczególnie cenne, ponieważ obok nazw ludowych podawała także nazwy łacińskie opisywanych gatunków, co umożliwiało ich identyfikacje. W listach do Rostafińskiego pojawiały się również jej pytania dotyczące sposobów gromadzenia zbiorów zielnikowych oraz prośby o konsultacje naukowe. Twardowska korzystała z jego pomocy w oznaczaniu niektórych gatunków wierzb, a także przesyłała mu zebrane okazy ${ }^{63}$. Kontakt z Rostafińskim prawdopodobnie wykraczał poza 1888 r. Ścisłe relacje naukowe utrzymywała również z Dybowskim. Choć w tym przypadku nie mamy potwierdzenia w korespondencji, Bolesław Hryniewiecki ${ }^{64}$ podaje, że przesłała Dybowskiemu 54 gatunki roślin z Polesia do przygotowywanego zielnika i była jedną z jego najrzetelniejszych współpracowniczek ${ }^{65}$. W źródłach nie znajdujemy też potwierdzenia jej kontaktów z Edwardem Janczewskim i Franciszkiem Chłapowskim. Florystka z Weleśnicy, która z powodu sytuacji osobistej (i politycznej) przebywała jedynie w majątkach należących do męża i rodziny Skirmuntów, jako pierwsza kobieta została członkiem Komisji Fizjograficznej Akademii Umiejętności w Krakowie ${ }^{66}$. Wybór został zatwierdzony przez Wydział III AU w 1904 r. i pomimo sprzeciwu Zarządu AU, Komisja przyjęła Marię Twardowską jako współpracowniczkę ${ }^{67}$.

60 powo.science.kew.org/taxon/224409-1 [dostęp 30.11.2020]; compositae.landcareresearch.co.nz/?Page=NameDetails\&Nameld=32EFB728-F520-44EC-AC40-5EA001B5C19F [dostęp 30.11.2020].

61 Dybowski podawał jastrzębce występujące w okolicach swojego majątku Niańkowa (zanotował 19 gatunków i podgatunków jastrzębca z tego obszaru).

62 W. Dybowski, O jastrzębcach nowogródzkich, „Wszechświat” t. 16, 1897, nr 10, s. 156-157.

63 A. Piekiełko-Zemanek, P. Köhler, op. cit., s. 474-478.

64 Bolesław Hryniewiecki (1875-1963) - profesor systematyki i geografii roślin na Uniwersytecie Warszawskim. W latach 1926-1927 pełnił funkcję rektora uczelni. Był dyrektorem Ogrodu Botanicznego Uniwersytetu Warszawskiego, członkiem Towarzystwa Naukowego Warszawskiego, Polskiej Akademii Umiejętności i Polskiej Akademii Nauk. Zob.: W. Gajewski, Bolesław Hryniewiecki (1875-1963), „Acta Societatis Botanicorum Poloniae” t. $32,1963, \mathrm{nr} 3$, s. $463-472$.

65 Z. Wójcik, O Władysławie Dybowskim (1838-1910) i jego działalności naukowej, „Analecta” t. 12, 2003, nr 1, s. 171; B. Hryniewiecki, op. cit., Warszawa 1933, s. 14.

66 Komisja Fizjograficzna funkcjonowała na Wydziale Matematyczno-Przyrodniczym w Akademii Umiejętności. Została podzielona na pięć sekcji. Twardowska uczestniczyła w pracach sekcji botanicznej, której przewodniczącym w latach 1903-1913 był Janczewski; zob. Rocznik Akademii Umiejętności w Krakowie. Rok 1903/1904, Kraków 1907, s. 52-54; Rocznik Akademii Umiejętności w Krakowie. Rok 1906/1907, Kraków 1907, s. 48-50; F. Chłapowski, op. cit., s. 320.

67 P. Köhler, Dzieje botaniki w Towarzystwie Naukowym Krakowskim, Akademii Umiejętności i Polskiej Akademii Umiejętności (1815-1952), „Prace Komisji Historii Nauki Polskiej Akademii Umiejętności” t. 5, 2003, s. 86. 
Poza badaniami na polu botaniki Twardowska wiodła żywot zgodny z naczelnymi wartościami życia ziemiańskiego na Kresach. Pozostawała wierna religii rzymskokatolickiej i swoich religijnych uczuć nie omieszkała uzewnętrzniać. Chłapowski podkreślał tę cechę w jej biogramie: „Głęboko religijna i pobożna, przykładem swym świeci drugim, a w rozumieniu zadań prawdziwej chrześcijanki wznosi się w mało komu dostępne wyżyny życia duchowego"68. Realizowała ideał społecznego posłannictwa pań z dworu. Ziemianki kresowe z pokolenia urodzonego w II połowie XIX w. odczuwały przytłoczenie wąskimi ramami dotychczasowej egzystencji i coraz odważniej realizowały się na szerszym polu użyteczności społecznej, czego świadectwem było podnoszenie poziomu wykształcenia, zakładanie tajnych pensji, szkół ludowych, ochronek dla dzieci, aktywność w różnego rodzaju organizacjach dobroczynnych itd. Twardowska na tym polu również zaznaczyła swoją obecność. W tym miejscu warto przypomnieć jej związki z wybitnymi kobietami w rodzinie Skirmuntów, które dzięki swoim przymiotom osobowości i aktywności na niwie społecznej zostały zapamiętane przez potomnych, a ich życiorysy utrwalone w historiografii. Na pierwszy plan wysuwają się tu Helena Skirmunt (1827-1874) i jej córka Konstancja Skirmunt (1851-1934). Helena Skirmunt, rzeźbiarka, malarka, uczestniczka powstania styczniowego i zesłanka była stryjenką Marii, żoną Kazimierza (1824-1893) - brata jej ojca Konstantego, ale łączyły je również więzy pokrewieństwa, ponieważ była ona jedynym dzieckiem Aleksandra Tomasza Skirmunta i Hortensji z Ordów ${ }^{69}$. Córka Heleny, Konstancja, stryjeczna siostra Marii starsza od niej o 7 lat, popularyzatorka historii, publicystka, propagatorka pojednania polsko-litewskiego, zwolenniczka emancypacji politycznej kobiet, była jedną z najbardziej wyrazistych kresowych działaczek społecznych z przełomu XIX i XX w. Jej portret polityczny został nakreślony przez Dariusza Szpopera w biografii Gente Lithunana, natione Lithuana ${ }^{70}$. Maria utrzymywała z nimi bliskie stosunki rodzinne, a z niewiele starszą od siebie Konstancją pozostawała w przyjaźni. Wspólne zaangażowanie w sprawy społeczne przedstawicielek rodu Skirmuntów było związane z Pińszczyzną ${ }^{71}$. Aktywnie działały między innymi w Katolickim Towarzystwie Dobroczynności w Pińsku, którego założycielką była Hortensja Skirmunt. W funkcjonowanie tej organizacji była zaangażowana również Twardowska, która w 1904 r., kiedy zdecydowano się na ujawnienie nielegalnego stowarzyszenia, stanęła wraz z Aleksandrem Skirmuntem z Porzecza na jego czele ${ }^{72}$. Towarzystwo skupione przy pińskim kościele parafialnym koncentrowało się na opiece nad najuboższymi dziećmi. Chłapowski w pośmiertnej nocie o Twardowskiej wspominał również o jej udziale w szerzeniu oświaty wśród miejscowej ludności. W okresie wzmożonej rusyfikacji konspiracyjna działalność oświatowa skierowana na potrzeby ludności wiejskiej, stanowiła odpór wobec dążeń rządu rosyjskiego do rozbudzenia antypolskich nastrojów. Na ślady działalności tajnej szkoły w Weleśnicy nie udało się natrafić, niemniej publikacje o charakterze edukacyjnym skierowane do warstw plebejskich, które Twardowska wyda-

69 J. Polanowska, Skirmunttowa ze Skirmunttów Helena, [w:] Polski Słownik Biograficzny, t. 38/2, Warszawa Kraków 1998, s. 187.

70 D. Szpoper, op. cit., Gdańsk 2009.

71 Helena urodziła się w Pińsku, Konstancja w majątku pod Pińskiem - Kołodnem.

72 D. Szpoper, op. cit., s. 89. 
wała, oraz relacja Chłapowskiego, który odnotował powściągliwie, że roztaczała opiekę nad „żądną oświaty czeladką”, mogą skłaniać do przypuszczeń, że była zaangażowana w szkolnictwo konspiracyjne. Karol Estreicher wymienia dwa tytuły książek o charakterze edukacyjnym, które były przez mieszkankę Weleśnicy przetłumaczone z niemieckiego na język polski, dostosowane do realiów guberni północno-zachodnich Cesarstwa Rosyjskiego i jej staraniem opublikowane w Warszawie w połowie lat dziewięćdziesiątych XIX w. ${ }^{73}$ Pierwszy tytuł „Gorzałka"74, liczący 56 stron, został wydany nakładem Wydawnictwa Księgarni Krajowej Prószyńskiego, Gebethner i Wolffa w 1894 r. Książka była przeznaczona dla młodzieży, która nie ma świadomości skutków zdrowotnych i finansowych używania alkoholu. Drugi tytuł O oszczędności kilka słów dla ludzi pracujących, opublikowany przez Wydawnictwo Gebethner i Wolff w 1895 r. był zaadresowany do osób pracujący fizycznie, których autorka stara się ustrzec przed nałogami i hazardem ${ }^{75}$. Twardowska stała się propagatorką ruchu abstynenckiego, który w realiach popowstaniowych na terenie guberni zachodnich Rosji nie miał szansy na funkcjonowanie w ramach legalnych organizacji (jak w Wielkopolsce czy w Królestwie Polskim). Jej udział w tajnej edukacji nie ma odbicia w źródłach, należy jednak pamiętać, że organizatorzy zakonspirowanych szkół starali się zatrzeć wszelkie ślady swojej działalności ${ }^{76}$.

Twardowska włączyła się również w nurt obchodów mickiewiczowskich 1898 r. Wraz ze Konstancją Skirmunt podjęła zamiar wydania księgi pamiątkowej ku czci Adama Mickiewicza $^{77}$. Do współautorstwa zaproszeni zostali znani literaci, ludzie nauki i sztuki. Główną ideą przyświecającą inicjatorkom monografii była rekonstrukcja świadomości historycznej mieszkańców dawnego Wielkiego Księstwa Litewskiego. Współautorów księgi pamiątkowej dobierano starannie, dbając o poziom merytoryczny materiałów i nowatorstwo w podejściu do badanej tematyki ${ }^{78}$. Efektem ich starań było opublikowanie w 1899 r. pracy zbiorowej pt. Z ziemi pagórków leśnych, z ziemi łąk zielonych. Książka zbiorowa poświęcona pamięci Adama Mickiewicza w stuletnią rocznicę Jego urodzin. Zamieszone zostały w niej teksty m.in. Czesława Jankowskiego, Edwarda Pawłowicza, Władysława Zahorskiego, Ignacego Balińskiego, Lucjana Uziębły, Marii Rodziewiczówny. Księga zawiera również dwa artykuły botaników. Teksty Janczewskiego, dawnego nauczyciela Twardowskiej, oraz Dybowskiego mają charakter przyrodniczych studiów naukowych i dotyczą litewskiej flo$\mathrm{ry}^{79}$. W książce znajdujemy także szkic historyczny Konstancji Skirmunt ${ }^{80}$. Trudno ustalić, czy pojawiło się również opracowanie Marii Twardowskiej. Tekst źródłowy Wyjątki z niewydanych dotąd pamiętników lgnacego Domeyki został opatrzony kryptonimem „M.T."81,

73 K. Estreicher, Bibliografia polska XIX stulecia. Lata 1881-1900, t. 4, Kraków 1916, s. 416.

74 Gorzałka, tłum. M. ze Skirmuntów Twardowska, Warszawa 1894.

75 O oszczędności słów kilka dla ludzi pracujących, tłum. M. ze Skirmuntów Twardowska, Warszawa 1895.

76 Por. I. Krasińska, Ruch abstynencki w Wielkopolsce w latach 1840-1902, „Folia Historica Cracoviensia” t. 19, 2013, s. 247-278; Pijaństwo i alkoholizm w piśmiennictwie Królestwa Polskiego w XIX i na początku XX wieku. Aspekty społeczne, pedagogiczne i kulturowe, wyb. źródeł i oprac. A. Bołdyrew, Łódź 2019.

77 D. Szpoper, op. cit., s. 129.

78 lbid.

79 E. Janczewski, Nieprzyjaciel pół naszych, [w:] Z ziemi pagórków leśnych, z ziemi łąk zielonych. Książka zbiorowa poświęcona pamięci Adama Mickiewicza w stuletnią rocznicę Jego urodzin, Warszawa 1899, s. 392-395; W. Dybowski, Rośliny litewskie w poezjach Adama Mickiewicza, [w:] Z ziemi pagórków leśnych, s. 396-406.

80 K. Skirmunttówna, Zbliżenie Litwy z Zachodem za Mendoga i Giedymina, [w:] Z ziemi pagórków leśnych, s. $112-131$.

81 M.T., Wyjątki z niewydanych dotąd pamiętników Ignacego Domeyki, [w:] Z ziemi pagórków leśnych, s. 15-34. 
co może wskazywać autorstwo botaniczki z Weleśnicy (takiego używała wielokrotnie, publikując we „Wszechświecie”).

\section{$* * *$}

Przedwczesna śmierć Marii Twardowskiej przerwała jej działalność społeczną i naukową. Zmarła w Weleśnicy 15 listopada 1907 r. w wieku 49 lat ${ }^{82}$. Nie znamy okoliczności jej śmierci. Chłapowski wspomniał o chorobie z jaką się zmagała: „Walcząc z nieubłaganą chorobą wzbudza podziw nie tylko cierpliwością, z jaką znosi wielkie boleści, ale i pogodą ducha i wielkim spokojem, z jakim bliskiego oczekuje końca"83. W nocie pośmiertnej zamieszczonej w „Dzienniku Wileńskim” Dybowski napisał również o jej „długich i niezmiernie bolesnych cierpieniach"84. Została pochowana na cmentarzu katolickim w Pińsku - jej nagrobek z inskrypcją daty śmierci zachował się do dnia dzisiejszego ${ }^{85}$. W czasie I wojny światowej dwór w Weleśnicy wraz z budynkami gospodarczymi uległ całkowitemu zniszczeniu $^{86}$. Spłonęło całe wyposażenie dworu: dzieła sztuki, bogata biblioteka i rodzinne $\operatorname{archiwum}^{87}$. Pamięć o mieszkance Weleśnicy utrwalona została jedynie w jej artykułach i w zasuszonych przez nią roślinach, które zgodnie z jej ostatnią wolą zostały przesłane do Poznania.

Losy zielnika Marii Twardowskiej ze Skirmuntów są trudne do odtworzenia. Mocą testamentu w 1907 r. trafił on do Poznańskiego Towarzystwa Przyjaciół Nauk wraz z opublikowanymi tomami wydawnictwa zielnikowego „Flora Polonica Exsiccata”. Można się zastanawiać, dlaczego litewska badaczka zdecydowała się na przekazanie zbiorów florystycznych - dzieła swojego życia - tej placówce naukowej88. Mogła o tym zadecydować wcześniejsza współpraca z Chłapowskim, kierownikiem Wydziału Przyrodniczego PTPN w latach 1888-1920. Twardowska przesłała mu w 1903 r. zbiór 46 okazów skrzypów, co zostało odnotowane podczas posiedzenia Towarzystwa ${ }^{89}$. Chłapowski był organizatorem Muzeum Przyrodniczego i zabiegał o pozyskiwanie eksponatów od prywatnych darczyńców ${ }^{90}$. Przekazany przez Twardowską zbiór został oceniony wysoko:

82 J. Mowszowicz, op. cit, s. 549.

83 F. Chłapowski, op. cit., s. 320.

84 W. Dybowski, Ś. P. Maria Twardowska, s. 1.

85 A. Lewkowska, J. Lewkowski, W. Walczak, Zabytkowe cmentarze na Kresach Wschodnich Drugiej Rzeczypospolitej. Województwo poleskie, Warszawa 2000, s. 136.

86 Kilka dzieł sztuki i szczątki z archiwum Twardowskich uratowano przed Niemcami (dokumenty według Michała Marczaka dotyczyły miejscowej szkoły założonej w I połowie XIX w.), jednak zaginęły podczas II wojny światowej. Dworu w Weleśnicy nie odbudowano. Ostatnim spadkobiercą majątku był Stefan Twardowski, bratanek Józefa Twardowskiego; zob. M. Marczak, op. cit., s. 138; Spis ziemian Rzeczypospolitej Polskiej w roku 1930. Województwo poleskie, województwo wołyńskie, oprac. T. Epsztein, S. Górzyński, Warszawa 1996, s. 34.

87 R, Aftanazy, op. cit., t. 2, s. 149.

88 Na temat niejasnych motywacji przekazywania zbiorów przyrodniczych Poznańskiemu Towarzystwu Przyjaciół Nauk zob. szerz. A. Pelczar, S. Marciniak, W. Alexandrowicz, Dyskusja po referacie Ryszarda Marciniaka „Związki Poznańskiego Towarzystwa Przyjaciół Nauk z polskimi ośrodkami naukowymi w okresie zaborów, „Prace Komisji Historii Nauki Polskiej Akademii Umiejętności” t. 8, 2008, s. 313-314.

89 Towarzystwo Przyjaciół Nauk w Poznaniu, „Rozwój” 1903, nr 279, 5 XII 1903 r., s. 3.

90 R. Meissner, Chłapowski Franciszek (1846-1923), [w:] Wielkopolski Słownik Biograficzny, red. A. Gąsiorowski, J. Topolski, Warszawa - Poznań 1981, s. 101; Poczet członków Poznańskiego Towarzystwa Przyjaciół Nauk 1857-2007, red. A. Pihan-Kijasowa, Poznań 2008, s. 111-112; A. Wrzosek, Chłapowski Franciszek (18451923), [w:] Polski Słownik Biograficzny, t. 3, Kraków 1937, s. 302-303 
Jest tego 5 dużych pak, które nadeszły. Wzbogaca to znacznie dotychczasowe florystyczne zbiory naszego Towarzystwa, które choć nie ubogie w zielniki (Bendy, F. Sypniewskiego, Kotlińskiego, Martina itd.) nie mają tej cechy i tej wartości dla fizyografii, co zielniki śp. Maryi Twardowskiej, bo albo są niekompletne, albo z różnych stron pochodzą i były zbierane więcej w celu dydaktycznym ${ }^{91}$.

Na posiedzeniu Wydziału Przyrodniczego i Technicznego, które miało miejsce w dniu 7 stycznia 1908 r. Chłapowski doniósł o darze, który wkrótce miał zostać Towarzystwu dostarczony. Ze sprawozdania wynika, że były problemy z tymczasowym ulokowaniem zbioru Twardowskiej - nie mógł być bezpośrednio umieszczony w Muzeum Przyrodniczym, jak również w mieszkaniu Chłapowskiego. Podjęto wówczas decyzję, że cenna przesyłka trafi do mieszkania wiceprezesa PTPN, Heliodora Święcickiego ${ }^{92}$. Uporządkowanie zbioru i przygotowanie go do publicznej ekspozycji zostało powierzone nieznanemu z imienia aptekarzowi Koniecznemu93. Trudno stwierdzić, czy wywiązał się on ze zleconego mu zadania - nie znajdujemy informacji, kiedy kolekcja florystyczna Twardowskiej ujrzała światło dzienne i została zaprezentowana szerszej publiczności. Na ślad zielnika natrafiamy dwie dekady później. Wychodzący w Poznaniu "Nowy Kurier" z 1927 r. donosił o eksponatach w Oddziale Przyrodniczym Muzeum Wielkopolskiego. W 1924 r. nastąpiła komasacja zbiorów przyrodniczych Muzeum Wielkopolskiego ze zbiorami PTPN, które znalazły miejsce w wyremontowanym pawilonie restauracyjnym na terenie Ogrodu Zoologicznego na Jeżycach. Organizacja Oddziału Przyrodniczego Muzeum trwała przez cały 1925 r., a oficjalne jego otwarcie miało miejsce 27 IV 1927 r. Do nowej siedziby zostały przeniesione zbiory PTPN, liczące 7455 numerów, pośród których znalazł się zielnik Marii Twardowskiej ${ }^{94}$. Na łamach „Nowego Kuriera” czytamy:

Zbiory Muzeum Przyrodniczego mieszczą się w dwóch dużych salach i w kilku pobocznych ubikacjach. Pracownie Muzeum chociaż nie tak piękne jak zagraniczne, no ale na początek niezłe. Mamy tam pracownię fotograficzną, preparatorską, macernię, no i wreszcie podręczną bibliotekę. Zobaczmy same zbiory. W sali głównej dział zoologiczny i botaniczny. Oprócz grzybów reprezentują dział ten obszerne herbarja, m.in. zbiory Branda, prof. Raciborskiego ze Lwowa, prof. Szulczewskiego z Poznania i śp. Marji z Skirmuntów Twardowskiej ${ }^{95}$.

Eksponaty botaniczne były umieszczone w obszernych szklanych gablotach. Wystawa cieszyła się dużym zainteresowaniem zwiedzających - średnio rocznie kolekcje oglądało 4,5 tysiąca osób ${ }^{96}$. W niezmienionym układzie przetrwała do II wojny światowej ${ }^{97}$. Zbiory przyrodnicze zostały wywiezione przez władze niemieckie w październiku 1939 r. Część eksponatów zmagazynowano w budynku dzisiejszego Muzeum Narodowego, część zaś

91 F. Chłapowski, op. cit., s. 320.

92 „Przegląd Techniczny” t. 46, 1908, nr 5, s. 62.

93 F. Chłapowski, op. cit., s. 320.

94 T. Grabski, Oddział Przyrodniczy Muzeum Wielkopolskiego na Jeżycach w okresie międzywojennym, „Kronika Miasta Poznania" 2000, nr 2, s. 236-238.

95 „Nowy Kurier" r. 38, 1927, nr 1, 1 I 1927 r., s. 5.

96 Rekordowa frekwencja miała miejsce w 1929 r.; wówczas wystawę odwiedziło ponad 29 tys. osób.

97 A. Wróblewski, Historia zbiorów przyrodniczych, „Roczniki Historyczne” r. 23, 1957, s. 505. 
uległa rozproszeniu ${ }^{98}$. Zielnik Twardowskiej po wojnie nie został odnaleziony. Pojedyncze okazy zasuszonych i opisanych przez Twardowską roślin znajdują się dzięki wysyłce w ramach „Flora Polonica exsiccata” między innymi w Państwowym Uniwersytecie Iwana Franki we Lwowie, w Muzeum Historii Naturalnej Ukraińskiej Państwowej Akademii Nauk, w Szwedzkim Muzeum Historii Naturalnej w Sztokholmie, w Muzeum Botanicznym w Berlinie. Najliczniejszy zbiór okazów zebranych przez mieszkankę Weleśnicy jest w posiadaniu Muzeum Historii Naturalnej w Londynie ${ }^{99}$.

Marię Twardowską ze Skirmuntów trzeba zaliczyć do kobiet nietuzinkowych. Należała do pokolenia Polaków zamieszkujących gubernie północno-zachodnie Rosji szczególnie doświadczonego polityką represyjną w sferze narodowej, religijnej, kulturowej, społecznej. Ani płeć, ani ograniczenia wynikające z polityki rusyfikacyjnej, ani sytuacja rodzinna nie pohamowały jej botanicznej pasji. Pozostawiona przez nią spuścizna w postaci artykułów naukowych i popularnonaukowych ukazuje osobowość dociekliwą, otwartą i pracowitą. Ślady jej działalności społecznej odsłaniają pozytywistyczne nastawienie i zaangażowanie w życie najbliższej społeczności. Herbarium, które ofiarowała Franciszkowi Chłapowskiemu, choć nie przetrwało zawieruchy wojennej, stanowiło świadectwo zaangażowania w badanie flory krajowej.

\section{Bibliografia}

\section{Źródła rękopiśmienne}

Lietuvos mokslų akademijos Vrublevskių biblioteka [LMAVB], f. 7-518, Listy Marii Twardowskiej ze Skirmuntów do Józefa Bielińskiego z lat 1886-1895.

\section{Źródła drukowane}

Gorzałka, tłum. M. ze Skirmuntów Twardowska, Warszawa 1894.

Jankowski E., Wspomnienia ogrodnika, oprac. A. Szwejcerowa, A. Brachfogel, Warszawa 1972.

Niesiecki K., Herbarz Polski, t. 9, Lipsk 1839-1845

O oszczędności słów kilka dla ludzi pracujących, tłum. M. ze Skirmuntów Twardowska, Warszawa 1895.

Rocznik Akademii Umiejętności w Krakowie. Rok 1903/1904, Kraków 1907.

Rocznik Akademii Umiejętności w Krakowie. Rok 1906/1907, Kraków 1907.

Skirmunt K., Moje wspomnienia 1866-1945, oprac. E. Orlof, A. Pasternak, Rzeszów 1998.

Spis ziemian Rzeczypospolitej Polskiej w roku 1930. Województwo poleskie, województwo wołyńskie, oprac. T. Epsztein, S. Górzyński, Warszawa 1996.

X.Y.Z., Kartka z dziejów Kościoła Katolickiego w Rosyi. Biskupstwo Mińskie, Kraków 1887.

98 T. Grabski, op. cit., s. 242

99 Jstor. Global Plants, plants.jstor.org/search?filter=people\&so=ps_group_by_genus_species+asc\&Query=Twardowska [dostęp 16.08.2020]. 
Z ziemi pagórków leśnych, z ziemi łąk zielonych. Książka zbiorowa poświęcona pamięci Adama Mickiewicza w stuletnią rocznicę Jego urodzin, Warszawa 1899.

Żychliński T., Złota księga szlachty polskiej, r. 4 [Dodatki], Poznań 1882.

Żychliński T., Złota księga szlachty polskiej, t. 1, Poznań 1879.

\section{Źródła prasowe}

„Dziennik Wileński” r. 1907, nr 268, s. 1.

„Nowy Kurier" r. 38, 1927, nr 1, 1 I 1927 r., s. 5.

„Przegląd Techniczny” t. 46, 1908, nr 5, s. 62.

Chłapowski F., Śp. Maria ze Skirmuntów Twardowska, „Roczniki Towarzystwa Przyjaciół Nauk Poznańskiego" t. 34, 1908, s. 317-320.

Dybowski W., O jastrzębcach nowogródzkich, „Wszechświat” t. 16, 1897, nr 10, s. 156-157.

Towarzystwo Przyjaciół Nauk w Poznaniu, „Rozwój” 1903, nr 279, 5 XII 1903 r., s. 3.

Twardowska M., Bobry w Prusach Zachodnich, „Wszechświat” t. 20, 1901, nr 26, s. 410-413.

Twardowska M., Ciąg dalszy spisu roślin z okolic Szemetowszczyzny i z Weleśnicy, „Pamiętnik Fizjograficzny" t. 10, 1890, dział III, s. 261-272.

Twardowska M., Ciąg dalszy spisu roślin z okolic Szemetowszczyzny i z Weleśnicy, „Pamiętnik Fizjograficzny" t. 12, 1892, dział III, s. 199-208.

Twardowska M., Ciepło i życie, „Wszechświat” t. 8, 1889, nr 28, s. 440-443, nr 29, s. 462-464, nr 30, s. 477-479.

Twardowska M., Dodatek do spisu roślin znalezionych w okolicach Szemetowszczyzny na Litwie [...] i dodatek do przyczynka do flory Pińszczyzny [...], „Pamiętnik Fizjograficzny" t. 8, 1888, dział III, s. 215-220.

Twardowska M., Drzewo kawowe $i$ jego uprawa w Afryce, „Wszechświat” t. 19, 1900, nr 12, s. 184-186.

Twardowska M., Jubileusz F. Cohna we Wrocławiu, „Wszechświat” t. 17, 1898, nr 18, s. 287.

Twardowska M., Notatka o kilku rzadszych roślinach flory litewskiej, „Wszechświat” t. 10, 1891, nr 51, s. 814-815.

Twardowska M., Notatka o skrzypach znalezionych na Litwie w r. 1901, „Wszechświat” t. 12, 1903, nr 8, s. 122-123.

Twardowska M., Notaty florystyczne z Szemetowszczyzny i Weleśnicy, „Pamiętnik Fizjograficzny" t. 19, 1907, dział III, s. 41-43.

Twardowska M., Odmiany roślin rozmnażające się tylko przez gałęzie, „Wszechświat" t. 18, 1899, nr 2, s. 25-27.

Twardowska M., Przyczynek do flory Pińszczyzny, „Pamiętnik Fizjograficzny” t. 4, 1884, dział III, s. 423-433.

Twardowska M., Przykład przystosowania rośliny do zapylenia przez ptaki, „Wszechświat” t. 19,1900, nr 16, s. 250-251.

Twardowska M. Roboty jesienne bobrów, „Wszechświat” t. 17, 1898, nr 30, s. 779-780.

Twardowska M., Rozpowszechnianie roślin przez mrówki, „Wszechświat” t. 19, 1900, nr 8, s. 123-124.

Twardowska M., Spis roślin z Szemetowszczyzny i Weleśnicy w latach 1893-1894, „Pamiętnik Fizjograficzny" t. 14, 1896, dział III, s. 115-118.

Twardowska M., Spis roślin z Szemetowszczyzny i Weleśnicy, „Pamiętnik Fizjograficzny” t. 17, 1902, dział III, s. 95-99. 
Twardowska M., Spis roślin znalezionych w okolicy Szemetowszczyzny na Litwie, „Pamiętnik Fizjograficzny" t. 3, 1883, dział III, s. 274-291.

Twardowska M., Wiadomości o śluzowcach znalezionych w latach 1778-1883, „Pamiętnik Fizjograficzny" t. 5, 1885, dział III, s. 160-163.

Twardowska M., Z czego robi się kauczuk, „Wszechświat” t. 18, 1899, nr 46, s. 730-732.

Twardowska M., Z nad brzegów Jasiołdy, „Wszechświat” t. 8, 1889, nr 30, s. 480-481.

Valigny H., La Temperature et la vie, „Revue des Deux Mondes” t. 93, 1889, nr 1, s. 176-201.

\section{Literatura przedmiotu}

Aftanazy R., Dzieje rezydencji na dawnych kresach Rzeczypospolitej, t. 2, Wrocław - Warszawa - Kraków 1992, t. 4, Wrocław - Warszawa - Kraków 1993.

Brzoza Cz. Stepan K., Skirmunt Roman (1868-1839), [w:] Polski Słownik Biograficzny, t. 38, Wrocław 1997-1998, s. 184-197.

Estreicher K., Bibliografia polska XIX stulecia. Lata 1881-1900, t. 4, Kraków 1916.

Fokciński H., Kazimierz Skirmunt (1861-1931), [w:] Polski Słownik Biograficzny, t. 38, Wrocław 1997-1998, s. 177.

Gajewski W., Bolesław Hryniewiecki (1875-1963), „Acta Societatis Botanicorum Poloniae” t. 32, 1963, nr 3, s. 463-472.

Grabski T., Oddział Przyrodniczy Muzeum Wielkopolskiego na Jeżycach w okresie międzywojennym, „Kronika Miasta Poznania” 2000, nr 2, s. 236-238.

Hryniewiecki B., Udział kobiety polskiej w rozwoju botaniki, Warszawa 1933.

Ilgiewicz H., Helena Romer Ochenkowska (1875-1947) i jej pamiętniki, [w:] Polskie dziwiętnastowieczne listy i pamiętniki z Ziem Zabranych - rola $i$ miejsce $w$ badaniach historycznych, red. W. Caban, L. Michalska-Bracha, Warszawa 2017, s. 475-488.

Jelski A., Weleśnica, [w:] Słownik geograficzny Królestwa Polskiego i innych krajów słowiańskich, red. B. Chlebowski, F. Sulimierski, W. Walewski, t. 13, Warszawa 1893, s. 314.

Jurkowski R., Ziemiaństwo polskie Kresów Północno-Wschodnich 1864-1904, Warszawa 2001.

Köhler P., Dzieje botaniki w Towarzystwie Naukowym Krakowskim, Akademii Umiejętności i Polskiej Akademii Umiejętności (1815-1952), „Prace Komisji Historii Nauki Polskiej Akademii Umiejętności" t. 5, 2003, s. 79-94.

Köhler P., Zielniki botaników ośrodka wileńskiego z lat 1780-1840 w Kijowie, Krakowie i Wilnie, „Kwartalnik Historii Nauki i Techniki” t. 39, 1994, nr 1, s. 109-116.

Konarski S., Aleksander Skirmunt 1798-1870, [w:] Polski Słownik Biograficzny, t. 38, Wrocław 1997-1998, s. 175-176.

Kras J., Wyższe Kursy dla Kobiet im. A. Baranieckiego w Krakowie 1868-1924, Kraków 1972.

Krasińska I., Ruch abstynencki w Wielkopolsce w latach 1840-1902, „Folia Historica Cracoviensia" t. 19, 2013, s. 247-278, DOI 10.15633/fhc.240.

Lewkowska A., Lewkowski J., Walczak W., Zabytkowe cmentarze na Kresach Wschodnich Drugiej Rzeczypospolitej. Województwo poleskie, Warszawa 2000.

Majewski T., Botanika w warszawskich czasopismach „Pamiętnik Fizjograficzny" $i$ „Wszechświat”, „Analecta” t. 14, 2005, nr 1, s. 147-165.

Majewski T., Edward Franciszek Glinka Janczewski (1846-1918), [w:] Złota Księga Uniwersytetu Jagiellońskiego, red. A. Zemanek, cz. 1, Biografie Uczonych, Kraków 2000, s. 75-82. 
Marczak M., Przewodnik po Polesiu, Brześć 1935.

Meissner R., Chłapowski Franciszek (1846-1923), [w:] Wielkopolski Słownik Biograficzny, red. A. Gąsiorowski, J. Topolski, Warszawa - Poznań 1981, s. 101.

Niepodległość z kobiecą twarzą. Różne przejawy aktywności kobiet w drodze do niepodległości (od upadku powstania styczniowego do 1920 roku), red. T. Skoczek, Warszawa 2019.

Nowak-Kiełbikowa M., Konstanty Skirmunt (1861-1931), [w:] Polski Słownik Biograficzny, t. 38, Wrocław 1997-1998, s. 177-183.

Nowak-Kiełbikowa M., Konstanty Skirmunt. Polityk i dyplomata, Warszawa 1998.

Pelczar A., Marciniak S., Alexandrowicz W., Dyskusja po referacie Ryszarda Marciniaka „Związki Poznańskiego Towarzystwa Przyjaciół Nauk z polskimi ośrodkami naukowymi w okresie zaborów, „Prace Komisji Historii Nauki Polskiej Akademii Umiejętności” t. 8, 2008, s. 309-315.

Piekiełko-Zemanek A., Köhler P., Józefa Rostafińskiego odezwa do nie botaników o zbieranie ludowych nazw roślin i udział w niej Marii Twardowskiej, „Kwartalnik Historii Nauki i Techniki" t. 31, 1986, nr 2, s. 471-480.

Pijaństwo i alkoholizm w piśmiennictwie Królestwa Polskiego w XIX i na początku XX wieku. Aspekty społeczne, pedagogiczne i kulturowe, wyb. źródeł i oprac. A. Bołdyrew, Łódź 2019.

Poczet członków Poznańskiego Towarzystwa Przyjaciół Nauk 1857-2007, red. A. Pihan-Kijasowa, Poznań 2008.

Polanowska J., Skirmunttowa ze Skirmunttów Helena, [w:] Polski Słownik Biograficzny, t. 38/2, Warszawa - Kraków 1998, s. 187.

Rostafiński J., Historia Kursów Wyższych dla Kobiet im. A. Baranieckiego, Kraków 1900.

Skirmuntt R., Panie z Muru, "Słowo” 1934, nr 125, s. 3.

Sławiński W., Przyczynek do znajomości okolic Wilna. Cz. 1 - Historia i bibliografia, Wilno 1922.

Słownik biologów polskich, red. S. Felisiak, Warszawa 1987.

Szargot B., Sentymentalny profesor. Ślady lektury w listach przyrodnika, „Rocznik Komparatystyczny" 2018, nr 9, s. 253-266, DOI 10.18276/rk.2019.9-15.

Szpoper D., Gente Lithuana, natione Lithuana. Myśl polityczna i działalność Konstancji Skirmuntt (1851-1934), Gdańsk 2009

Wołkowycki W., Zróżnicowanie szaty roślinnej pogranicza Europy Środkowo-Wschodniej i Północno-Wschodniej, [w:] Z Mazowsza na Polesie, Zróżnicowanie i ochrona szaty roślinnej pogranicza Europy Środkowej i Północno-Wschodniej, red. A. Obidziński, Warszawa 2010, s. 9-37.

Wójcik Z., O Władysławie Dybowskim (1838-1910) i jego działalności naukowej, „Analecta" t. 12, 2003, nr 1, s. 165-175.

Wróblewski A., Historia zbiorów przyrodniczych, „Roczniki Historyczne” r. 23, 1957, s. 501-508.

Wrzosek A., Bieliński Józef, [w:] Polski Słownik Biograficzny, t. 2, Kraków 1936, s. 52.

Wrzosek A., Chłapowski Franciszek (1845-1923), [w:] Polski Słownik Biograficzny, t. 3, Kraków 1937, s. 302-303.

Ziemianie polscy XX wieku. Słownik biograficzny, t. 3, cz. 1, red. J. Leskiewiczowa, Warszawa 1992. 
Złobin E., „Niechaj Polska zna, jakich synów ma”. Rok 1863 na Pińszczyźnie, „Echa Polesia" 2013, nr 1, s. 21-25.

\section{Strony internetowe}

powo.science.kew.org/taxon/224409-1 [dostęp 30.11.2020].

compositae.landcareresearch.co.nz/?Page $=$ NameDetails $\&$ Nameld $=32 \mathrm{EFB728}-\mathrm{F} 520-44 \mathrm{EC}$ -

-AC40-5EA001B5C19F [dostęp 30.11.2020].

plants.jstor.org/search?filter=people\&so=ps_group_by_genus_species +asc\&Query-

=Twardowska [dostęp 16.08.2020].

dr hab. n. hum. Maria Korybut-Marciniak, pracownik Instytutu Historii Uniwersytetu Warmińsko-Mazurskiego w Olsztynie. W centrum swoich zainteresowań badawczych stawia historię społeczną ze szczególnym uwzględnieniem ziemiaństwa, inteligencji oraz społecznie odrzuconych w XIX w. na obszarze ziem litewsko-białoruskich.

e-mail: maria.korybut-marciniak@uwm.edu.pl

dr Karolina Studnicka-Mariańczyk, pracownik Instytutu Historii Uniwersytetu Humanistyczno-Przyrodniczego im. Jana Długosza w Częstochowie. Zainteresowania naukowe: historia XIX i XX w., w szczególności historia gospodarcza, kulturalna i myśli społecznej, historia ziemiaństwa, kultury materialnej.

e-mail: k.studnicka@ujd.edu.pl

Data zgłoszenia artykułu: 15 października 2020

Data przyjęcia do druku: 8 stycznia 2021 